The 49th Annual Conference of the International Association of School Librarianship

The 24th International Forum on Research on School Librarianship

July $12-16,2021$

\begin{abstract}
Alice Bamigbola
University of Ibadan, Ibadan, Nigeria

aa.bamigbola@ui.edu.ng
\end{abstract}

\title{
School Libraries Role in Connected Learning: Perception of School librarians in Nigeria
}

\begin{abstract}
Connected learning (CL) aims at bridging the gap between in-school and out-of-school learning, thus, learning now takes place not only in the classroom setting. Libraries as nexus of informal learning space are appropriate spaces for connected learning. Observation shows that CL has not been embraced in Nigeria. Therefore, this study examined the perception of school librarians on the roles of school libraries in CL, challenges of CL, and solutions. School librarians that attended the national workshop organized by the Nigerian School Library Association (NSLA) participated in the focus group discussion. The findings revealed perceived roles of school libraries in CL, challenges of CL in Nigeria, and solutions proffered.
\end{abstract}

Keywords: connected learning, Nigeria, school libraries

\section{Introduction}

Innovations are synonymous with the technological advancement of the 21 st Century. Innovations are evident in every sphere of human endeavors, in particular, in learning environments of this era. Innovations in education present diverse tools and platforms for learning. One of such innovations of this era is Connected Learning (CL). It makes learning to be connected everywhere, not necessarily in the classroom setting. CL allows learners to learn at their discretion, based on their interest and relevant contexts, thus, collaborate, share and give feedback freely.

According to Ito et al. (2013), "connected learning addresses the gap between in-school and out-of-school learning, intergenerational disconnects, and new equity gaps arising from the privatization of learning" (p. 4). As a result, learning is now connected anywhere by anybody without discrimination of status, color, or race. Therefore, CL is a mode of learning that aims to connect the often-separate domains or settings of interest-based, peer-supported, and academic or career-oriented learning (Martin, 2015). As a result, Cornwell and Cornwell (2013) described 21 st Century learning as learner-centered, active, quality, current, and relevant content, well designed, technology-enabled, self-improving, self-reforming, and self-documenting that aims at producing lifelong learners. 
Libraries, as the hub of informal learning space, have embraced CL, thus, "connected libraries" are emerging (Martin, 2015). Connected libraries link learners, making them learn amidst their peers, in their interesting contexts, and relevant academic/career orientation in diverse spheres. Many libraries across the globe have embraced CL, and as a result, libraries have metamorphosed into learning hubs where learning takes place through several platforms. However, observation and review of literature show that CL has not been adopted in school libraries in Nigeria; also, there seems to be no study on connected learning in school libraries in Nigeria. On this premise, this study investigates the perception of school librarians on the role of school libraries in connected learning in Nigeria. It also identifies challenges of connected learning in school libraries and proffers ways forward.

\section{Statement of the Research Problem}

Many school libraries across the globe have adopted connected learning to bridge the gap between in-school and out-of-school learning, indeed, CL has proved to be a learning framework of this age. Observation shows that $\mathrm{CL}$ is yet to be embraced in school libraries in Nigeria, and a literature search shows that there seem to be no studies on CL in school libraries in Nigeria. On this premise, this study aims to investigate the perception of school librarians on the role of school libraries in connected learning.

The main objective of this study is to examine the perception of school librarians on the role of school libraries in connected learning in Nigeria. The specific objectives are to:

1. identify the role of school libraries in connected learning as perceived by the school librarians in Nigeria,

2. examine challenges of connected learning in school libraries in Nigeria,

3. identify solution to challenges of connected learning in school libraries in Nigeria.

To achieve the stated objectives three research questions were answered.

1. What are the roles of school libraries in connected learning?

2. What are the challenges of connected learning in school libraries in Nigeria?

3. What is the solution to the challenges of connected learning in school libraries in Nigeria?

\section{Literature review}

Learning is categorized into three forms: formal, non-formal, and informal. The categorization is based on the controlling agent, what is being learnt, and how it is being learnt. Formal learning is institutionalized, with mandatory curriculum-based, while non-formal is based on voluntary participation in an educational institution but outside the formal education, and the learner tacitly controls the goals but the institution controls the means of achieving the goals. 
Informal learning consists of the forms of learning outside both formal and non-formal settings (Bilandzic, 2016). Informal learning is therefore referred to as free-choice learning, "the learning people do when they get to control what to learn, when to learn, where to learn, and with whom to learn" (Falk \& Dierking, 2002, p. 6). It has been observed that learners are naturally motivated to learn more in an informal learning environment when learning is self-directed and self-controlled than when learning is controlled by an external body.

Innovations and emerging technologies are paving ways for several self-directed, self-controlled, and learner-centered environments in the 21 st Century. One of such is Connected Learning (CL). In particular, technology has revolutionized learning to the extent that learners connect learning not only within the classroom wall but now in homes, libraries, after school clubs, religious institutions, play centers, and community centers. However, connected learning is not technology-centered, but social and learner-centered. Learning is connected through parents, teachers, friends, mentors, and coaches at diverse locations.

Connected learning was coined in 2013 by Ito to bridge the gap between formal and informal learning. Ito et al., (2013) defined connected learning as "an educational framework that emphasizes learning experiences that are "socially embedded, interest-driven, and oriented toward educational, economic, or political opportunity" (p. 4). Thus, CL stands on a tripod of interest, relationship (peer-supported), and opportunity (academic/career/political oriented), and its core properties include experiences that are production-centered, a shared purpose, and openly networked infrastructures (Martin, 2015). Therefore, connected learning is achieved when a young person can pursue a personal interest or passion with the support of friends and caring adults/mentors, and he/she can link what was learnt to academic achievement, career success, and civic engagement. Thus, CL is situated in sociocultural learning theory that stresses the fact that learning takes place where there is teacher-student collaboration, experiential learning, peer interactions, and problem-solving activities (Jaramillo, 1996 as cited by Hoffman et al., 2016). It is obvious that to achieve CL, apart from the three contexts (interest, relationship, and opportunity), the core properties: production-centered, shared purpose and open network infrastructures are critical. Therefore, an open space with network infrastructures where the purpose would be freely shared is germane to functional CL.

The right place in an educational setting that can accommodate the core properties of CL is the library. Libraries as centers for knowledge creation and sharing, with the technological innovations of this era, are considered to be ideal environments for supporting connected learning. Libraries support self-directed and interest-focused learning. This is possible because of inclusive public spaces in libraries that accommodate different groups and support learning that is both peer-supported and has a shared purpose with others (Hoffman et al., 2016). In addition, libraries are linking agents to the communities and can provide mentoring and expertise needed, 
because librarians are regarded as ideal mentors that assist youths to connect learning from interest spaces to academic and career spaces (Hoffman et al., 2016).

Since the inception of CL, libraries in developed countries, especially public libraries, have embraced it. Some of the notable examples of CL in libraries are "Hanging out, messing around and geek out" (HOMAGO) in Houston Public Library where participants "geek out" in a multi-week course on video game design and Providence Public Library, Rhode Island who organized a fashion designing and making session where interested Teens geek out and made their dresses (Hoffman, et al., 2016). Similarly, Bilandzic (2016) reported an interactive learning environment tagged "Hack The Evening" (HTE) where participants engaged in electronics through Do-It-Yourself (DIY) technology, such as Arduino microcontrollers, 3D printers, or gesture recognition devices at the State Library of Queensland in Brisbane, Australia. The implication is that public libraries in developed countries are increasingly adopting CL to engage youths in informal learning that is production-centered, interest-inspired, and socially embedded.

However, there are challenges to connected learning in the libraries, such as the building of relationships with learners and partners, inadequate infrastructure, lack of required skills by librarians, and resources limitation (Bilandzic, 2016; Hoffman et al., 2016; Ito et al., 2013).

\section{Methodology}

The study employed a qualitative research approach. The participants of the study comprised 36 school librarians who participated in the national workshop organized by the Nigerian School Library Association (NSLA) held in October 2019 at Ibadan, Nigeria. Focus Group Discussion (FGD) was used to collect data, in three sessions; each session had 12 respondents in attendance. The FGD sessions included brainstorming, discussion, and documenting ideas. Each session lasted for one hour and fifteen minutes; the researcher first presented an overview of connected learning in school libraries to the participants, thereafter, the participants brainstormed, discussed, and documented ideas based on four crucial questions. The following questions were used to elicit data from the participants. The first question, (1) what do you understand by connected learning? was asked before the presentation of the overview of connected learning. The other questions were asked after the presentation: (2) What are the roles of school libraries in connected learning? (3) What are the challenges of connected learning in school libraries in Nigeria and (4) What is the solution to the challenges of connected learning in school libraries in Nigeria? Answers to these questions were recorded, transcribed, and analyzed.

\section{Findings}

The findings are reported below:

\section{What do you understand by connected learning?}

Most of them ( 30 out of $36 ; 83 \%$ ) had no previous idea of what connected learning means, while the remaining $(6 ; 17 \%)$ mistook makerspace for connected learning. 


\section{What are the roles of school libraries in connected learning?}

The participants perceived that school libraries are to facilitate connected learning in schools by providing infrastructures such as space for production centers, computers, and serve as agents of link with partners beyond the library community.

\section{What are the challenges of connected learning in school libraries in Nigeria?}

Challenges of connected learning as revealed by the participants are lack of needed resources, such as lack of space, inadequate funding, poor infrastructural facilities (furniture, computers, epileptic power supply and Internet connectivity); lack of awareness, passive attitude of school librarians, unskilled school librarians and unresponsiveness of the government.

\section{What is the solution to the challenges of connected learning in school libraries in Nigeria?}

The participants gave solutions to overcome the challenges of connected learning in school libraries in Nigeria. The solutions are awareness creation, fundraising, proactiveness of the librarians, empowerment of librarians, and advocacy for policy.

\section{Discussion}

The findings of this study revealed that the majority of the participants had no idea of connected learning before the presentation of the overview of connected learning by the researcher while a few of them mistook makerspaces for connected learning. The impact of this is that there was no awareness about connected learning by school librarians in Nigeria at the time of the study. However, this study created awareness of connected learning for the participants at the workshop.

This study identified the following roles of school libraries in connected learning; provision of learning space, infrastructures such as furniture, computers, power supply, and internet connectivity. Other items to be provided by school libraries are resources in terms of materials, equipment, and tools. In addition, school libraries are to perform the role of agent/link to connect partners and other stakeholders and mentoring roles. This is in agreement with the submission of Bilandzic (2016), Hoffman et al. (2016), and Martin (2015).

Regarding challenges of connected learning in school libraries in Nigeria, the findings revealed lack of space, lack of infrastructure, epileptic power supply, poor internet connectivity, inadequate funding, lack of awareness about connected learning, passive attitude of school librarians, and unresponsive attitude of the government. Some of these challenges corroborated by Hoffman et al. (2016) show that resource limitation and specialized skills required for librarians working with the youths are challenges to connected learning. The findings also concur with the finding of Bilandzic (2016), that averred that the spatial infrastructure of the library was 
a challenge because of the connected learning "Hack-The-Evening" group's needs. On the other hand, some of the challenges of connected learning found in this study are location specifically, that is, they are peculiar to Nigeria.

Lastly, the solutions suggested by the participants are the creation of awareness of connected learning by professional bodies such as the Nigerian School Library Association in the form of workshops and seminars. Similarly, proactiveness of the school librarians towards innovations and creativities, regular attendance of conferences, and on-the-job training and development to equip school librarians for the 21 st Century required skills. Others are advocacy and fundraising, sourcing of donations, and provision of infrastructure by the government. These findings correspond with the Hoffman et al. (2016) study which proffered that school librarians should think big and consider all the possibilities to source for funds to solve the challenges of resource limitations.

\section{Implications and Conclusion}

This study revealed that connected learning is a relatively new concept to the participants (school librarians) in Nigeria. It implies that connected learning has not been embraced in Nigeria because the school librarians that ought to be at the forefront of implementing it were not aware of the concept. However, the participants were quick to assimilate it and they were able to come up with some perceived roles of school libraries in connected learning, challenges, and possible solutions. One of the challenges of connected learning in Nigeria is the fact that the awareness is low, hence, there is a need for awareness creation. This can be done through workshops and conferences to be organized by the professional bodies.

School libraries in developing countries like Nigeria that are confronted with a myriad of challenges may not be able to start on innovative ideas that will be capital intensive, however, starting on a low key will be an option. School librarians need to think out of the box, be proactive, and come out with innovative ideas within the available resources. Similarly, school librarians should avail themselves of skill-building opportunities, such as in-service personal development to equip themselves. Networking and collaboration with colleagues in the developed countries could also help in sharing innovative ideas and resources.

\section{References}

Bilandzic, M. (2016) Connected learning in the library as a product of hacking, making, social diversity, and messiness. Interactive Learning Environments, 24,(1), 158 -177.

Cornwell, W. R. \& Cornwell, J. R. (2006). Connected learning: A framework of observation, research and development to guide the reform of education, Breckenridge, $\mathrm{CO}$ : The Center for Internet research http:/tcfir.org/whitepapers/connected\%20Learning\%20Framework.pdf

Falk, J. H., \& Dierking, L. D. (2002). Lessons without limit: how free-choice learning is transforming education. Walnut Creek: Alta Mira Press. 
Hoffman, K. M., Subramaniam, M., Kawas, S., Scaff, L., \& Davis, K. (2016). Connected libraries: Surveying the current landscape and charting a path to the future. College Park, MD; Seattle, WA: The ConnectedLib Project.

https://papers.ssrn.com/sol3/papers.cfm?abstract_id=2982532

Ito, M., Gutiérrez, K., Livingstone, S., Penuel, B., Rhodes, J., Salen, K., Schor, J., Sefton-Green, J., \& Watkins, S. C. (2013). Connected learning: An agenda for research and design. Irvine, CA: Digital Media and Learning Research Hub. http://dmlhub.net/publications/connected-learning-agenda-for-research-and-design/index .html

Jaramillo, J. A. (1996). Vygotsky's sociocultural theory and contributions to the development of constructivist curricula. Education, 117(12), 133-140.

Martin, C. (2015) Connected learning, librarians, and connecting youth interest. Journal of Research on Libraries and Young Adult: The Future of Library Services for and with Teens (themed issue), 6(1), 1-25

http://www.yalsa.ala.org/jrlya/2015/03/connected-learning-librarians-and-connecting-y outh-interest/ 